\title{
The Accumulation of Phenolic Acids \\ in Tissue Culture Pathogen Combinations of Solanum tuberosum and Phytophthora infestans
}

\author{
By N. F. ROBERTSON, J. FRIEND, MURIEL AVEYARD, \\ JEAN BROWN, MARGARET HUFFEE AND ANNA L. HOMANS \\ Department of Botany, The University, Hull
}

(Accepted for publication 4 July 1968 )

SUMMARY

Suspended tissue cultures of R I-resistant Solanum tuberosum infected with race 4 sporangia of Phytophthora infestans developed toxicity in the culture fluid when tested after Io days against a zoospore suspension of $P$. infestans. The toxic material was extracted into ether and salicylic, vanillic and $p$ hydroxybenzoic acids were identified in the toxic fraction by thin-layer chromatography, gas-liquid chromatography and mass spectrometry. Quantitative estimates of the amounts of material present in the toxic fraction allowed a mixture to be made which closely simulated the natural toxic material. Use of pure materials allowed an analysis of the behaviour of the zoospores with variation in dosage.

\section{INTRODUCTION}

Evidence for an 'immunizing' effect of pre-infection of cut slices of potato with an avirulent race of Phytophthora infestans was given by Müller \& Börger (1940) from a study of the response of a series of potato varieties differing in susceptibility to $P$. infestans. Müller \& Behr (1949) suggested that the resistance of the potato to $P$. infestans was the result of the production of substances, named by them 'phytoalexins', inimical to the invading fungus. The concept that resistance to attack by a wide spectrum of fungal pathogens and non-pathogens was engendered by the production of nonspecific phytoalexins was further explored by Müller (1958) for Phytophthora infestans and Monilinia fructigena with Phaseolus vulgaris pods as host tissue, and by Cruickshank \& Perrin (1965) for Monilinia fructicola and Ascochyta pisi with Pisum sativum as host. This and other work, summarized by Cruickshank (I963), led to the view that where a host actively resisted invasion by a pathogen a phytoalexin was produced as a response to fungal invasion. Such phytoalexins so far identified are relatively simple aromatic polycyclic compounds; work on the identification of phytoalexins has been confined to the products of plants acting as non-congenial hosts for a wide variety of fungi; some, e.g. pisatin, are also produced in response to tissue poisoning by compounds of heavy metals (Cruickshank \& Perrin, 1965). Tomiyama et al. (I968) demonstrated and Katsui et al. (1968) characterized a new antifungal substance rishitin, which qualified as a phytoalexin, from tuber tissues of potatoes infected by an incompatible race of $P$. infestans. This suggested that the R gene-resistance system may also be based on the post-infectional production of phytoalexins. 
Ingram \& Robertson (1965) showed that tissue aggregates derived from tubers of Solanum tuberosum var. Orion (R I ) resisted the attack of Phytophthora infestans race 4. Ingram (1967) showed that, in contrast to suspended tissue cultures of cultivar Majestic, suspended tissue cultures of cultivar Orion inoculated with sporangia of $P$. infestans race 4 showed a subsequent development of toxicity such that the germination of test zoospores was totally prevented by the tissue-culture liquid I $44 \mathrm{hr}$ after initial infection. The nature of this toxic material is investigated below.

\section{METHODS}

Growth of tissue cultures. The methods used were in general as described by Ingram \& Robertson (1965) and Ingram (1967). To increase the quantity of material for extraction Erlenmeyer flasks (I 1.) each containing $100 \mathrm{ml}$. of a dense 8-week Solanum tuberosum tissue suspension were inoculated with $10^{6}$ sporangia of Phytophthora infestans and tested at intervals for the development of toxicity. Cultures of this size inoculated in this way generally showed marked toxicity at 10 days, as did parallel cultures prepared exactly as described by Ingram (1967). This was in contrast to the 6-day period for the full development of toxicity shown by Ingram. The same culture stock was used and there was a gradual increase in the time to development of full toxicity over the 3 years of this investigation. This increase was accompanied by a gradual change in the appearance of the cultures. These were at first dark brown and slow-growing and are now paler and grow faster. Ingram (1966) referred to a fastgrowing white sector which developed in callus tissue cultures and which showed less marked resistance than the brown parent material. It appears likely that during the work reported here we have been selecting for faster growth of the suspended tissue cultures and there has been a parallel increase in the time required for the development of toxicity by the cultures. As soon as toxicity was noted the cultures were extracted. Control flasks of inoculated Majestic tissue cultures or uninoculated Orion tissue cultures, of the same age and cultural treatment, were harvested along with infected Orion cultures. Parallel experiments were done with tissue slices removed aseptically from tubers of Orion and Majestic.

Tests for toxicity. Qualitative tests for toxicity of extracts were made by inoculating $0.1 \mathrm{ml}$. of the material for assay with $\mathrm{I} \times \mathrm{IO}^{4}$ freshly hatched zoospores on a clean sterile slide and estimating the degree of lysis or shrinkage of the zoospores in several fields after $10 \mathrm{~min}$. Where quantitative estimates were required the method was modified and $0.5 \mathrm{ml}$. of solution at twice the required final concentration was mixed with $0.5 \mathrm{ml}$. of zoospore suspension adjusted to give 50,000 zoospores $/ \mathrm{ml}$. before dilution and 25,000 zoospores/ml. after mixing in the test solution. Then four drops of the mixture were placed on a slide and the percentage lysis of all zoospores in any 6 fields of the microscope, taken at random, was found after $3 \mathrm{hr}$. and, where required, the average germ-tube length after a $5 \mathrm{hr}$. period. Both methods of measurement gave similar estimates of the LD 50 dose of toxic material.

Chemical extraction of toxic material. At harvest, the tissue culture (usually $120 \mathrm{ml}$.) was filtered (suction) through acid-washed celite and the clear filtrate extracted with one-sixth of its volume of redistilled ether in a separating funnel. The extraction was repeated 6 times and the ether extracts ( $120 \mathrm{ml}$.) mixed. A $10 \mathrm{ml}$. portion of the mixed ether extract was evaporated under suction to dryness, the vessel flushed with nitrogen 
and the residue taken up in $\mathrm{I} \mathrm{ml}$. distilled water before testing for toxicity. The aqueous solution remaining after extraction with ether was then evaporated in a rotary evaporator to remove remaining ether and a sample tested for toxicity against a standard zoospore suspension.

Gas chromatography. Before gas-liquid chromatography, an evaporated sample of the ether extract dissolved in pyridine was treated with hexamethyl disilazane (HMDS) in the presence of catalytic amounts of trimethyl chlorosilane (TMCS) to form volatile trimethyl silyl ethers and esters by the procedure of Dalgleish et al. (1966).

Derivatives of standard phenolic acids were prepared in a similar manner. Chromatographic separations were done by using a Perkin Elmer F. I I gas chromatograph fitted with a biomedical flame-ionization analyser, used in the single-column mode. Samples (usually I $\mu$ l.) were injected into a $6 \mathrm{ft}$. $\times \frac{1}{4}$ in. (O.D.) glass column packed with $3 \%$ SE 3 oI on AW-DCMS Chromosorb G. The temperature of the injection area was $270^{\circ}$, the oven temperature $175^{\circ}$; and the nitrogen carrier-gas flow-rate was $33 \mathrm{ml} . / \mathrm{min}$.

Thin-layer chromatography. MN Silica Gel G and silica gel/MN cellulose 300 plates, $20 \mathrm{~cm} . \times 20 \mathrm{~cm}$. glass, with the solvent system toluene + ethyl formate + formic acid $5+4+\mathrm{I}$ by vol. (Van Sumere, Wolf, Teuchy \& Kint, 1965) were used for the analyses of extracts. Samples of phenolic acids dissolved in ether were used as standards. The plates were first examined under ultraviolet radiation (wavelength $365 \mathrm{~nm}$.) and then sprayed with $2 \mathrm{~N}-\mathrm{NaOH}$ and again viewed by u.v. radiation to observe colour changes. The plates were then sprayed with diazotized $p$-nitroaniline and then with $5 \%(\mathrm{w} / \mathrm{v})$ $\mathrm{Na}_{2} \mathrm{CO}_{3}$ (Van Sumere et al. 1965).

Ultraviolet spectrophotometry. Spectra were measured in $\mathrm{I} \mathrm{cm}$. optical cells using a Beckman DK-2A recording spectrophotometer.

\section{RESULTS}

\section{Evidence for identification of compounds}

The toxicity which developed in tissue cultures of potato Orion (R I) when infected with Phytophthora infestans race 4 did not develop in tissue cultures of Majestic (rr) infected with race 4 over the same period of time nor did it appear in uninfected cultures of Orion.

The toxic fraction was removed by shaking the tissue culture filtrate with a variety of solvents immiscible with water (e.g. chloroform, butanol, ethyl acetate, ether); the best of these was ether because of the ease of recovery of the extracts at low temperatures and because, in contrast to the other solvents, re-distilled ether left no toxic residue after evaporation. Zoospore tests of the aqueous solution after extraction with re-distilled ether showed that all the detectable toxicity had been transferred to the ether. The ethereal solution was extracted either with $3 \%$ aqueous $\mathrm{Na}_{2} \mathrm{CO}_{3}$ or with $\mathrm{I}$ and $5 \% \mathrm{NaOH}$ aqueous solution; the toxic fraction was recovered on acidification. At this point thin-layer chromatography showed the presence of one blue fluorescent and two deep purple (due to absorption) spots in the ethereal extract under u.v. radiation which gave colour reactions with diazotized compounds. The phenolic nature of at least one of the components of the extract was indicated by measurement of the difference spectrum between a portion of extract adjusted to $\mathrm{pH} 7$ and another 
adjusted to $\mathrm{pH}$ 12.3 which showed a peak at $298 \mathrm{~nm}$., indicative of a non-conjugated phenolic hydroxyl group (Goldschmidt, 1954).

Mass-spectrographic examinations of a sample of the total ether extract of the infected Orion toxic material was made on an AEI MS902 instrument. Peaks were present which indicated compounds having mass numbers of 138 (corresponding to salicylic and $p$-hydroxybenzoic acids), I68 (corresponding to vanillic acid) and 178 (which might be a small amount of coniferaldehyde).

Gas-liquid chromatography of the trimethylsilylated extracts showed three wellseparated peaks with retention times at $2 \cdot \mathrm{I}, 3.2$ and $5.2 \mathrm{~min}$. These retention times corresponded with those for salicyclic acid, $p$-hydroxybenzoic acid and vanillic acid, respectively. Further gas chromatography of the Orion tissue culture toxic material and a mixture of vanillic, salicylic and $p$-hydroxybenzoic acid gave identical traces.

Thin-layer chromatography of the ether extract showed three main compounds which reacted with the diazotized $p$-nitroaniline spray and which had the same $R_{F}$ values and colour reactions as salicylic, $p$-hydroxybenzoic and vanillic acids, respectively. The extract was then streaked on the plate and the areas of the plate corresponding to the sprayed marker spots were scraped off, eluted with ether and analysed individually by gas-liquid chromatography; each showed a single peak with a retention time corresponding to the standards, and the mass-spectrographic analysis of each gave the appropriate mass number (see Table I). Concentrates of the eluted spots were toxic when tested against zoospores of Phytophthora infestans.

Table I. Toxic material from Phytophthora infestans: identity of bands separated by thin-layer chromatography and comparison of the properties of the bands with standard compound

$\begin{array}{lcccc}\text { Band } & \boldsymbol{R}_{F} \text { on TLC } & \begin{array}{c}\text { Colour with } \\ \text { diazo spray }\end{array} & \begin{array}{c}\text { Retention time of } \\ \text { TMS derivative } \\ \text { (min.) }\end{array} & \begin{array}{c}\text { Mass } \\ \text { no. }\end{array} \\ \text { I } & 0.46 & \text { Pink } & 3.5 & 138 \\ 2 & 0.5 \mathrm{I} & \text { Purple } & 5.4 & 168 \\ 3 & 0.61 & \text { Ochre } & 2 \cdot I & 138 \\ \text { Salicylic acid } & 0.61 & \text { Ochre } & 2 \cdot 1 & 138 \\ p \text {-Hydroxybenzoic acid } & 0.46 & \text { Pink } & 3.4 & 138 \\ \text { Vanillic acid } & 0.52 & \text { Purple } & 5.4 & 168\end{array}$

\section{Quantitative estimations}

Once the identity of the toxic compounds had been established it was of interest to determine the concentrations at which they were toxic and to look critically at the methods of assay. Müller (1958) tested a diluted series of suspected phytoalexins from Phaseolus and Pisum against newly hatched zoospores of Phytophthora infestans and noted that the normal response of the zoospores to high concentrations of phytoalexin was plasmoptysis within $60 \mathrm{sec}$., but that occasionally zoospores did not show plasmoptysis at lethal concentrations; in these cases shrinkage only took place. Müller used a dosage-response curve to define the LD 50 dose and calculated the relative concentration in units derived from the reciprocal of the dilution fraction for the LD 50 dose. Thus a dilution of $\mathrm{I} / 8$ produced a mean germination rate of $50 \%$ and was taken to contain 8 units phytoalexin. When Sclerotinia fructicola was used for 
assay the same calculations were made; but instead, with the LD 50 dose, a decrease to $50 \%$ of the mean germ-tube length was recorded. We used known amounts of pure salicylic, vanillic and $p$-hydroxybenzoic acid singly and together, and found that plasmoptysis invariably occurred in concentrations in excess of about 20 p.p.m., and that just below this concentration zoospores did not disintegrate but shrank and turned brown. These brown zoospores did not germinate, but some zoospores which did not shrink germinated and the numbers which germinated and the length of the germ tubes increased as the material underwent further dilution. The situation was further complicated by the effect of spore numbers. When zoospore numbers were large the effect of the toxic material was less than when the numbers were small.

It was of interest to discover what concentrations of toxic material were present in the infected tissue-culture liquor. Calibration of the peak area against concentration on an appropriate range of the gas chromatograph showed a straight-line relationship which could be used for quantitative estimates. When such estimates were made they varied between different sets of biological material; but the relative proportions of the three acids remained in the same order. In a typical experiment harvested on 9 January 1968 the pooled contents of 12 flasks of Orion tissue infected by Phytophthora infestans on 21 December 1967 were calculated to contain I2.85 p.p.m. total phenolic acids in the aqueous layer. These were in the proportions salicylic:vanillic:p-hydroxybenzoic acid :: I I $: 46: 27$. Since a single flask yielded $7 \cdot 78 \mathrm{~g}$. fresh wt tissue, the approximate yield of toxic material was $47 \mu \mathrm{g}$. $/ \mathrm{g}$. fresh cell wt.

To verify this estimation an artificial mixture in the proportions given above was made up (mixture $Z$ ) and tested on the same day in a dilution series in parallel with the original Orion extract; the results showed that the natural toxic material had an LD 50 dose of 12.5 p.p.m., while that of the mixture was 25 p.p.m. This suggested that the extract of Orion tissue culture might have contained small quantities of other materials which increased its toxicity. Thin-layer chromatography plates did show traces of other materials which were not characterized on these plates or by gas chromatography. There was also a degree of variability in the test zoospores. The $\mathrm{LD}_{50}$ dose for mixture $\mathrm{Z}$ was determined on nine different occasions and varied from 16.5 to 34.5 p.p.m.

It remains to be asked whether the extraction of phenolic acids from the mixture and the tests for toxicity in aqueous solution did not artificially exaggerate the part played by these substances. Mixture Z, containing a total of 185 p.p.m. in water, was at $\mathrm{pH}$ 3.3. Tests on zoospores with phosphate and acetate buffers showed that the buffers themselves caused lysis at all $\mathrm{pH}$ values. Very dilute solutions of $\mathrm{HCl}$ allowed us to examine a range from $\mathrm{pH} 2$ to $\mathrm{pH} 4.5$. The zoospores of Phytophthora infestans germinated well at $\mathrm{pH}_{3.7}$; above $\mathrm{pH}_{3.3}$ the zoospores lysed. However, mixture $\mathrm{Z}$ at a dilution giving 18.5 p.p.m., which was the value normally found in experiments, was at $\mathrm{pH} 4 \cdot 3$, suggesting that the $\mathrm{pH}$ value of the phenolic acids, at the concentrations normally tested, was not responsible for the zoospore inhibition. The reverse situation when, for example, salicylic acid was added to fresh tissue culture medium ( $\mathrm{pH} 5.6$ ) showed that the concentration of the acid had to be raised to 200 p.p.m. (4.85) to bring about total zoospore lysis. When tissue culture medium in which potato cells of cultivar Majestic had grown for 4 weeks $(\mathrm{pH} 5 \cdot 8)$ was used, lysis and inhibition were obtained at 100 p.p.m. salicylic acid added $\left(\mathrm{pH}_{4} \cdot \mathrm{I}\right)$. Finally, when sodium salicylate was tested against zoospores it inhibited germination at 25 p.p.m., but not at I2.5 p.p.m. 
In this work we did not observe any marked difference in the degrees of toxicity of the three acids or any evidence of synergistic effects of the mixture.

\section{DISCUSSION}

It is well understood that there is a change in the metabolism of infected resistant tissues of plants in the direction of the accumulation of phenolic substances (Farkas \& Kiraly, 1962). There are certain difficulties in interpretation of results, however, for attempted invasion is accompanied to a greater or lesser extent by death of the invaded tissues. At one extreme a single cell will undergo necrosis following invasion and the invading hypha will not be able to grow further, e.g. the invasion of the cells of R gene-resistant potatoes by Phytophthora infestans. At the other extreme, invasion of a tuber will proceed for a considerable distance before death of the tissue takes place. It has thus been difficult to determine how far the phenolic materials produced are a response to invasion by the fungus and how far they are a consequence of the death of the plant cells. Müller's approach to the problem (1956, 1958) was to compare the materials secreted into the infection drops over a short period of time when inoculum, in water, was placed on exactly comparable resistant and susceptible varieties and the infection drop was then assayed for toxicity at intervals against freshly hatched zoospores of Phtophthora infestans. Although Müller's work began with $P$. infestans and potato, he found it convenient to develop his investigations with pods of Phaseolus vulgaris as recipients of massive infective doses of $P$. infestans and Monilinia fructicola. In the investigation reported here tissue culture suspensions were used because Ingram had shown that they reacted in a comparable manner to whole plants and because the liquid in which the tissues and infecting spores were suspended acted as a very large 'infection drop' and allowed the accumulation of reasonably large amounts of any inhibitory substances. Also, there was a marked difference between freely growing tissue cultures and freshly cut potato tuber slices, which tended to show the production of phenols (Tomiyama, 1963) as a wound reaction. Against this, it must be made clear that tissue-culture cell walls of potato have greater amounts of lignin than normal cells and that $P$. infestans can grown to a limited extent in the tissue culture medium with consequent metabolic effects. However, it is felt that the demonstration by Ingram that toxic substance(s) accumulate in infected suspended tissue cultures of cultivar Orion (RI resistant) while it fails to accumulate in uninfected suspended tissue cultures of cultivar Orion or infected suspended tissue cultures of cultivar Majestic, is reasonable ground for suggesting that the toxic material might be associated with the resistance reaction and might in fact be a 'phytoalexin'.

Investigation of the toxic tissue-culture media has shown the consistent presence of three simple benzoic acids, namely $p$-hydroxybenzoic, vanillic and salicylic acids, as the chief constituents. Moreover, during the fractionation procedure, toxicity increased step by step with procedures which eventually led to the isolation of these acids, and a mixture of the acids in the proportions of and at concentrations comparable to that found in the toxic tissue-culture fluid did closely parallel the natural toxin when compared in a dilution series, and gave a similar value for the LD 50 dose.

It remains to be discovered whether these phenolic acids produced in this situation are of significance only in this situation, or whether they have a wider significance in the resistance of plants. Tomiyana et al. (1968) implicated as the potato phytoalexin 
a terpenoid, rishitin, which we did not find. From its structure it should be much less water-soluble than the benzoic acids and should not accumulate in the tissue culture medium. We have yet to test the tissue-culture cells for the accumulation of postinfection toxic material. On the other hand, Fawcett \& Spencer (I967) showed a postinfection accumulation of benzoic acids in resistant apple varieties infected with brown rot fungus. Since lignification of cell walls naturally follows infection of the potato (Knee, 1967, personal communication) and since the pathway to the benzoic acids would be via cinnamic acid, which also takes part in the synthesis of lignin (Pridham, 1965), we may have been dealing with a special modification of the lignification process in the resistant potato tissue culture. This modification would involve either the induction or activation of the $\beta$-oxidation pathway leading from cinnamic acids to benzoic acids. Until the relative amounts of lignin and benzoic acids formed can be estimated it is difficult to suggest whether or not benzoic acids are being formed at the expense of lignin or in addition to lignin. Experiments to investigate the change in metabolic pathways involving the cinnamic acids are at present in progress.

We acknowledge with thanks the receipt of a grant from the Agricultural Research Council which made this work possible.

\section{REFERENCES}

Cruickshank, I. A. M. (1963). Phytoalexins. A. Rev. Phytopathology I, 35 I.

Cruickshank, I. A. M. \& Perrin, D. R. (1965). Studies in phytoalexins VIII. The effect of some further factors on the formation, stability and localisation of pisatin in vivo. Aust. J. biol. Sci. I8, 8I 7 .

Dalgleish, C. E., Horning, E. C., Horning, M. G., KnoK, K. L. \& Yarger, K. (1966). A gasliquid chromatographic procedure for separating a wide range of metabolites occurring in urine or tissue extracts. Biochem. J. ror, 792.

Farkas, G. L. \& KIRALY, Z. (1962). Role of phenolic compounds in the physiology of plant diseases and disease reaction. Phytopath. Z. 44, 105.

FAWCETT, C. H. \& SPENCER, D. M. (1967). Antifungal phenolic acids in apple fruits after infection with Sclerotinia fructigena. Ann. appl. Biol. 6o, 87.

Goldschmm,, O. (1954). Determination of phenolic hydroxyl content of lignin preparations by ultraviolet spectrophotometry. Analyt. Chem. 26, 1421 .

IngRam, D. S. (1966). The interaction between Phytophthora infestans (Mont.) de Bary and tissue cultures of Solanum tuberosum. Ph.D. thesis, University of Hull.

INGRAM, D. S. (1967). The expression of R-gene resistance to Phytophthora infestans in tissue cultures of Solanum tuberosum. J. gen. Microbiol. 49, 99.

INGRAM, D. S. \& Robertson, N. F. (1965). Interaction between Phytophthora infestans and tissue cultures of Solanum tuberosum. J. gen. Microbiol. 40, $43 \mathrm{I}$.

Katsui, N., Murai, A., Takasugi, K., Imaizumi, K., Masamune, T. \& Tomiyama, K. (1968). The structure of Rishitin, a new antifungal compound from diseased potato tubers. Chem. Comm. no. $\mathbf{r}, 43$.

MülleR, K. O. (1956). Einige einfache Versuche zum Nachweis von Phytoalexinen. Phytopath. $Z$. 27, 237.

MülLER, K. O. (1958). Studies on phytoalexins. I. The formation and the immunological significance of phytoalexin produced by Phaseolus vulgaris in response to infections with Sclerotinia fructicola and Phytophthora infestans. Aust. J. biol. Sci. Ir, 275.

MülleR, K. O. \& BeHR, L. (I949). Mechanism of Phytophthora resistance of potatoes. Nature, Lond. r63, 469.

MülleR, K. O. \& BöRgeR, H. (1940). Experimentelle Untersuchungen uber die PhytophthoraResistenz der Kartoffel. Arb. biol. BundAnst. Land -u. Forstw. 23, 189.

Pridham, J. B. (1965). Low molecular weight phenols in higher plants. A. Rev. Pl. Physiol. 16, 13. 
TomiYama, K. (1963). Physiology and biochemistry of disease resistance of plants. A. Rev. Phytopathology $\mathbf{1}, 295$.

Tomiyama, K., Sakuma, T., Ishizaka, N., Sato, N., Katsui, N., Takasugi, M. \& Masamune, T. (1968). A new antifungal substance isolated from resistant potato tuber tissue infected by pathogens. Phytopathology 58, 115.

Van Sumere, C. F., Wolf, G., Teuchy, H. \& Kint, J. (1965). A new thin-layer method for phenolic substances and coumarins. J. Chromat. $20,48$. 